\title{
Suitability study of some surface water samples of Madhupur tract for irrigation, aquaculture and livestock consumption
}

\author{
MU Nizam ${ }^{1}$ MW Zaman ${ }^{2 *}$ MM Rahman², MS Islam³ \\ ${ }^{1}$ Department of Agricultural Chemistry, Patuakhali Science and Technology University, Potuakhali, \\ Bangladesh; $\quad{ }^{2}$ Department of Agricultural Chemistry, Bangladesh Agricultural University, Mymensingh 2202, \\ Bangladesh; ${ }^{3}$ Upazila Agriculture Officer, Department of Agriculture Extension, Dhaka, Bangladesh.
}

\begin{abstract}
Surface water samples from beel, river and canal of Madhupur Tract in Bangladesh were collected and analysed to find out the suitability of those water for irrigation, aquaculture and livestock consumption. Most of the samples were alkaline in nature only two samples were found acidic (pH 4.25 and 4.00). Out of 17 samples, 11 were limiting for irrigation and 15 were unsuitable for aquaculture with respect to $\mathrm{pH}$ values. Electrical conductivity (EC) rated maximum samples as "good" category for irrigation. TDS categorized the samples as "fresh water" for irrigation and were suitable for livestock, drinking and aquaculture. Chloride content of a few samples were beyond recommended limit for livestock. Micronutrient concentrations were alarming for livestock and aquaculture. $\mathrm{Cu}, \mathrm{Mn}$, Fe and $\mathrm{Zn}$ quantities categorized all the samples unsuitable for aquaculture. Most of the samples were also unsuitable for livestock due to higher Fe and Mn contents. $\mathrm{Ca}, \mathrm{Na}, \mathrm{K}$ and $\mathrm{P}$ quantities of all the samples were within safe limit for irrigation, aquaculture and livestock, but $\mathrm{Mg}$ contents of 8 samples were above recommended limit for aquaculture. Boron level classified 4 samples as "good" 13 as "excellent" for irrigation. SAR and EC combinedly rated all the samples as "medium salinity" and "low alkalinity" class (C2S1) and hardness categorized the waters in "soft", "moderately hard" and "hard water" class for irrigation. Considering all parameters not a single sample was found suitable for irrigation, livestock consumption, and aquaculture.
\end{abstract}

Key words: Madhupur tract, suitability, surface water, irrigation, aquaculture, livestock consumption

Progressive Agriculturists. All rights reserve

*Corresponding Author: zamanmw@gmail.com

\section{Introduction}

Water is an important element for the existence of life. It is prime component for irrigation, aquaculture and livestock farming. For every purpose, water should fulfill some standard. The supply of quality water is very difficult for different purpose of use as it is a natural substance. The quality of water varies widely for irrigation, aquaculture, and livestock consumption. Water is an universal solvent, various types of constituents are dissolved in it. Among soluble constituents in water, common major secondary constituents are $\mathrm{Ca}, \mathrm{Mg}, \mathrm{Na}, \mathrm{K}, \mathrm{Fe}, \mathrm{B}$,
$\mathrm{NO}_{3}, \mathrm{HCO}_{3}, \mathrm{SO}_{4}$ and $\mathrm{Cl}$ but minor or trace constituents are As, $\mathrm{Cd}, \mathrm{Cr}, \mathrm{Cu}, \mathrm{Mn}, \mathrm{P}$ and $\mathrm{Zn}$ (Davis and Weist, 1966) . Generally higher amount of dissolved constituents are present in ground water than in surface water because of the greater exposure to soluble materials in geologic strata (Todd, 1980). But sometimes surface water contains more dissolved constituents due to unusual activities of human. Surface water bodies of natural sources are polluted if the portions of water bodies are constantly getting some pollutants. Dissolved constituents 
above recommended limit for definite purpose treated as pollutants and they deteriorate the quality of water. For different types of use all constituents of water has an international standard limit such as the recommended concentration of $\mathrm{Cu}$ and $\mathrm{Fe}$ for irrigating soil are 0.2 and $5.0 \mathrm{mgL}^{-1}$ (Ayers and Westcot, 1985) ; for livestock consumption is 0.5 and $0.3 \mathrm{mg} \mathrm{L}^{-1}$ and for aquaculture, 0.03 and $<.01 \mathrm{ppm}$, respectively (Meade,1989). Most heavy metals and trace elements have reported to be extremely toxic to fish. Many fishes show respiratory distress with heavy metal toxicity. Lead can kill fishes at 0.33 ppm level. Similarly, $\mathrm{Hg}, \mathrm{Cd}, \mathrm{Cr}$, As, $\mathrm{Cu}$ can also be lethal at various concentrations. A concentration greater than $0.06 \mathrm{mg} \mathrm{L}^{-1}$ of cadmium can drastically affect the fish in water (Goel, 2006). Lethal $\mathrm{Cu}$ concentrations for fish and aquatic invertebrates range from 0.015 to $3.0 \mathrm{mg} \mathrm{L}^{-1}$. Mn in trace amounts is an essential nutrient element, required for normal function of cells. However, it is toxic at higher concentrations, and chronic exposure causes neurological disorders (Varshney, 2002).

The quality of water is judged by its total salt concentration, relative proportions of cations and anions; and the presence of toxic substances. So the chemical composition of water is a major factor in determining its suitability for different types of use. Irrigation water containing toxic ions such as $\mathrm{Na}, \mathrm{Li}$, $\mathrm{B}, \mathrm{HCO}_{3}$ and $\mathrm{Cl}$ at higher levels play an important role on the growth and development of crop plants because many field and fruit crops are susceptible to those elements (Bohn et al., 1985). Copper is toxic to many aquatic life at low concentrations. Algae are very sensitive to copper and can be killed at concentration as low as $0.5 \mathrm{mg} \mathrm{L}^{-1}$ (Goel, 2006). The use of low quality water for irrigation, aquaculture, and livestock farming may create ionic toxicity in plants, fishes and animals (Zaman and Rahman, 1996). In low land area of Madhupur Tract most of the farmers use natural surface water for irrigating HYV and local boro rice. Besides this, they use surface water for their livestock. The larval stages of fishes are highly sensitive to trace elements even at low concentration. A good number of indigenous fish species are going to be extinct due to the impairment of surface water quality. Since water is most important component of food chain, the suitability of water must be taken under consideration for irrigation, aquaculture and livestock consumption.

\section{Materials and Methods}

Seventeen surface water samples were collected from the Beel, river, canal and ponds of Madhupur Tract in Bangladesh following methods outline by APHA (2005).The analytical works were performed in the Department of Agricultural Chemistry, Bangladesh Agricultural University, Mymensingh.

The $\mathrm{pH}, \mathrm{EC}$ and TDS were determined following methods mentioned by Tandon (1995). $\mathrm{CO}_{3}$ and $\mathrm{HCO}_{3}$ were determined acidimetrically and argentometric titration was followed for the determination of $\mathrm{Cl}$ after Upadhyay and Sharma (2002).Ca and Mg were determined by complexometric method of titration Chopra and Kanwar (1986). Na and K were determined flame photometrically while $\mathrm{Zn}, \mathrm{Cu}, \mathrm{Fe}$ and $\mathrm{Mn}$ were determined with the help of AAS following method outlined by APHA (2005). Spectrophotometric method was followed for the determination of $\mathrm{P}$ and B (Page et al., 1982). Sodium adsorption ratio (SAR), soluble sodium percentage (SSP), residual sodium carbonate (RSC) and hardness $\left(\mathrm{H}_{\mathrm{T}}\right)$ of samples were calculated following standard formula mentioned by Mishra and Ahmed (1993), Richards (1968) and Michael (1997). Quality rating of the samples for irrigation was done following standard as mentioned by Wilcox (1955), Ayers and Westcot (1985), Freeze and Cherry (1979), Todd (1980), Sawyer and McCarty (1967), Eaton (1950) and Richards (1968). Aquaculture and livestock water quality was rated following standard outlined by Meade (1989), and Ayers and Westcot (1985), respectively. Statistical analyses were done following methods outlined by Gomez and Gomez (1984) with the help of computer package M-STAT. 


\section{Results and Discussion}

\section{pH, electrical conductivity (EC) and total dissolved solids (TDS)}

The $\mathrm{pH}$ of the surface water samples ranged from 4.00 to 10.13 with the mean value of 8.38 (Table1). Most of the waters were alkaline in nature. Only two samples collected from the beel water of Goair and Bandhabo village were acidic and the $\mathrm{pH}$ were 4.25 and 4.00, respectively (Table1). According to Ayers and Westcot (1985) the maximum recommended limit of $\mathrm{pH}$ for irrigation is 6.5 to 8.5. Based on their recommendation 11 samples were unsuitable for irrigation (Table2). The standard $\mathrm{pH}$ range for aquaculture is 6.5 to 8.0 Meade (1989). Most of the samples were also unsuitable for aquaculture.

Electrical conductivity (EC) of the waters varied from 177.92 to $533.76 \mu \mathrm{S} \mathrm{cm}{ }^{-1}$ having mean value of 358.40 (Table1). 15 samples were "good" and 2 were "excellent” class for irrigation after Wilcox (1955). Salinity and alkalinity hazard rated the samples "medium salinity" (C2) and "low alkalinity" (S1) class (Richards, 1968).

Total dissolved solids (TDS) of the samples ranged from 110.50 to $500.00 \mathrm{mg} \mathrm{L}^{-1}$ with the mean value of $358.40 \mathrm{mg} \mathrm{L}^{-1}$ (Table1). TDS categorized all the samples under "fresh water" for irrigation (Freeze and Cherry, 1979) and suitable for livestock drinking (Ayers and Westcot, 1985); according to Meade (1989) only one sample (TDS, $500.00 \mathrm{mg} \mathrm{L}^{-1}$, sample no. 7) was unsuitable for aquaculture (Table 2, 3 and 4) .

\section{Chloride (Cl), carbonate $\left(\mathrm{CO}_{3}\right)$ and bicarbonate $\left(\mathrm{HCO}_{3}\right)$}

The $\mathrm{Cl}$ concentration of the samples fluctuated from 0.4 to $2.00 \mathrm{me} \mathrm{L}^{-1}$, with the mean, SD and \%CV were 0.75, 0.39 and 52.09, respectively (Table1). Average $\mathrm{Cl}$ status of the present study was far below the $\mathrm{Cl}$ contents of the samples studied by Karim et al. (2013). They obtained higher $\mathrm{Cl}$ content because their study area was very close to the coastal belt of Bangladesh. From the $\mathrm{Cl}$ content of the present study, it was also clear that the $\mathrm{Cl}$ content of surface water generally decreased with the increase of distance of sea level. The recommended concentration of $\mathrm{Cl}$ for livestock is $30 \mathrm{mg} \mathrm{L}^{-1}$ (Ayers and Westcot, 1985). Based on their classification, $\mathrm{Cl}$ contents rated 12 samples suitable and 5 samples unsuitable for livestock drinking due to higher $\mathrm{Cl}$ (30 $\mathrm{mg} \mathrm{L}^{-1}$ ) concentration (Table 4).

Two samples responded to $\mathrm{CO}_{3}$ test and the values were1.00 and $2.00 \mathrm{me}^{-1}$. $\mathrm{HCO}_{3}$ ranged from 0.50 to $5.00 \mathrm{me} \mathrm{L}^{-1}$, with the average value of $2.88 \mathrm{me} \mathrm{L}^{-1}$. The presented average value of $\mathrm{HCO}_{3}$ was higher than that of the result of Karim et al. (2013) and similar to the findings of Nizam et al. (2010) and Taslima (2012). $\mathrm{HCO}_{3}$ content of the present samples would not be harmful for water supplying pipes.

Calcium (Ca), magnesium (Mg), sodium (Na) and potassium (K)

The quantities of $\mathrm{Ca}, \mathrm{Mg}, \mathrm{Na}$ and $\mathrm{K}$ were within the limit of 0.10 to $1.70,0.40$ to $4.00,0.086$ to 0.282 and 0.006 to $0.045 \mathrm{me}^{-1}$, respectively. The respective mean values were $0.72,1.67,0.17$ and $0.02 \mathrm{me}^{-}$

${ }^{1}$ (Table 1). Ca and Mg concentrations of the water samples of present study were almost similar to the findings of Karim et al. (2013) and Nizam et al. (2010). The Ca concentration of water for aquaculture should be within the range of 4.00 to $160.00 \mathrm{mg} \mathrm{L}^{-1}, \mathrm{Mg}<15.00 \mathrm{mg} \mathrm{L}^{-1}$ and $\mathrm{Na}$ is 75.00 $\mathrm{mg} \mathrm{L}^{-1}$ (Meade, 1989). The Ca and Na concentrations presented in Table 3 indicated that all the samples were suitable for aquaculture with respect to $\mathrm{Ca}$ and $\mathrm{Na}$ contents, while the Mg contents of 8 samples were above recommended limit and were unsuitable for aquaculture as $\mathrm{Mg}$ values were $>15 \mathrm{mg} \mathrm{L}^{-1}$ (Table 3). $\mathrm{K}$ contents also categorized all the samples suitable for aquaculture.

\section{Zinc ( $\mathrm{Zn})$, copper $(\mathrm{Cu})$, iron $(\mathrm{Fe})$ and manganese (Mn)}

$\mathrm{Zn}, \mathrm{Cu}, \mathrm{Fe}$ and $\mathrm{Mn}$ concentration of the samples fluctuated from 0.017 to 0.156 , trace to $0.320,0.088$ to 0.1 .795 and 0.030 to $0.926 \mathrm{mg} \mathrm{L}^{-1}$, respectively 
(Table 1). Zn and Fe contents rated all the samples suitable for irrigation. Fe and Mn concentrations of most of the samples were unsuitable for livestock drinking since Fe contents were $>0.3 \mathrm{mg} \mathrm{L}^{-1}$ and $\mathrm{Mn}$ contents were $>0.05 \mathrm{mg} \mathrm{L}^{-1}$, only two samples for Fe and one sample for $\mathrm{Mn}$ were within the recommended limit and were not toxic for livestock consumption (Table 4). Table 2 indicated that 6 samples for $\mathrm{Cu}$ and 5 samples for Mn concentrations were unsuitable for irrigating continuously on all soils (Ayers and Westcot, 1985). Zn and $\mathrm{Cu}$ values were within safe limit for livestock.

The larval stage of fishes are very sensitive to higher concentration of trace elements in natural water sources, which hampers the hatching of eggs and survibility of newly hatched larvae. As shown in Table 3, according to Meade (1989), Zn, Cu, Fe and Mn contents categorized all the samples unsuitable for aquaculture due to higher concentrations of these elements. It is assumed that a large number of indigenous fish species are going to extinct from the natural water bodies because of higher concentrations of trace elements.

\section{Phosphorus (P) and boron (B)}

$\mathrm{P}$ and $\mathrm{B}$ contents of the samples ranged from trace to 0.320 and 0.09 to $0.660 \mathrm{mg} \mathrm{L}^{-1}$, having mean value of 0.092 and $0.300 \mathrm{mgL}^{-1}$, respectively (Table1). Boron concentration is very important factor for irrigation. The recommended concentration of $\mathrm{B}$ for water used continuously on all soils is $<0.75 \mathrm{mg} \mathrm{L}^{-1}$. Based on Wilcox (1955), B contents rated 13 samples under "excellent" and 4 were "good" class for irrigation (Table2).

Soluble adsorption ratio (SAR), soluble sodium percentage (SSP), residual sodium carbonate (RSC) and hardness $\left(\mathrm{H}_{T}\right)$

The SAR values fluctuated from 0.063 to 0.297 . On the other hand, the SSP values ranged from 2.38 to $17.4 \%$ (Table 2). Based on the classification of Todd (1980) and Wilcox (1955) the SAR and SSP values categorized all the samples under "excellent" class for irrigation (Table2). Regarding salinity and alkalinity hazard SAR and EC rated the samples as "medium salinity" (C2) and "low alkalinity" (S1) and, combinedly expressed as (C2S1).

Residual sodium carbonate (RSC) and hardness (HT) ranged from -2.70 to +2.40 and 29.94 to $284.45 \mathrm{mg}$ $\mathrm{L}^{-1}$, respectively. According to Eaton (1950), RSC rated 9 samples as "suitable" and 8 samples “marginal” for irrigation (Table2). Following Sawyer and McCarty's (1967) classification, 5 samples were rated as "soft", 9 were "moderately hard" and 3 were "hard water" for irrigation (Table2). In the present study the higher hardness values of sample no. 4, 7 and 12 indicates higher $\mathrm{Mg}$ contents of the samples Similar findings were observed by Karanth (1994) in relation to water hardness and Mg concentration.

\section{Conclusion}

From results of chemical analysis of the water samples and comparison of the values with international standard recommendations of different organization and authors regarding irrigation, aquaculture and livestock drinking, it was found that elemental pollution existed in the surface water sources of Madhupur Tract. When one sample was found suitable for irrigation then it was unsuitable for aquaculture, on the other hand when another was found suitable for aquaculture then it was unsuitable for livestock consumption. None of the sample was found suitable for all the three purposes, irrigation, livestock drinking and aquaculture. Finally it can be concluded that the chemical quality of surface water sources of the study area must be checked to know its suitability for definite purpose and it will be help to protect any economic damage of field crops, fishes and livestock.

\section{References}

APHA (2005). Standard Methods for the Examination of Water and Wastewater. $21^{\text {st }}$ Edn. American Public Health Association, Washington DC, 20005. 
Table1. Sampling information and chemical constituents of water samples

\begin{tabular}{|c|c|c|c|c|c|c|c|c|c|c|c|c|c|c|c|c|c|c|}
\hline \multirow{2}{*}{$\begin{array}{c}\text { Samle } \\
\text { No. }\end{array}$} & \multirow{2}{*}{$\begin{array}{c}\text { Sampling } \\
\text { location } \\
\text { (Name of village) }\end{array}$} & \multirow{2}{*}{$\begin{array}{c}\text { Sources } \\
\text { of } \\
\text { water }\end{array}$} & \multirow{2}{*}{$\mathrm{pH}$} & \multirow{2}{*}{$\left(\begin{array}{c}\mathrm{EC} \\
\left(\mu \mathrm{S} \mathrm{cm}^{-1}\right)\end{array}\right.$} & \multirow{2}{*}{$\begin{array}{c}\text { TDS } \\
\left(\mathrm{mg} \mathrm{L}^{-1}\right)\end{array}$} & $\mathrm{Cl}$ & $\mathrm{CO}_{3}$ & $\mathrm{HCO}_{3}$ & $\mathrm{Ca}$ & $\mathrm{Mg}$ & $\mathrm{Na}$ & $\mathrm{K}$ & $\mathrm{Zn}$ & $\mathrm{Cu}$ & $\mathrm{Fe}$ & Mn & $\mathrm{P}$ & B \\
\hline & & & & & & \multicolumn{7}{|c|}{ me $L^{-1}$} & \multicolumn{6}{|c|}{$\mathrm{mg} \mathrm{L}^{-1}$} \\
\hline 1 & Goair & BW & 4.25 & 177.92 & 150.00 & 0.40 & Trace & 1.50 & 0.10 & 1.20 & 0.086 & 0.025 & 0.086 & 0.120 & 0.721 & 0.169 & 0.020 & 0.310 \\
\hline 2 & Boa & BW & 9.32 & 378.08 & 310.50 & 0.60 & Trace & 4.00 & 0.50 & 1.20 & 0.108 & 0.012 & 0.040 & 0.280 & 0.928 & 0.206 & 0.010 & 0.240 \\
\hline 3 & Kanserkul & RW & 8.20 & 400.32 & 335.50 & 0.60 & Trace & 4.00 & 0.80 & 2.20 & 0.173 & 0.022 & 0.076 & 0.220 & 0.530 & 0.081 & 0.180 & 0.210 \\
\hline 4 & Rajai & RW & 8.50 & 378.08 & 300.00 & 0.40 & Trace & 3.50 & 0.90 & 2.30 & 0.163 & 0.022 & 0.075 & 0.190 & 0.546 & 0.030 & 0.200 & 0.180 \\
\hline 5 & Rajai & BW & 8.33 & 400.32 & 290.50 & 0.60 & Trace & 3.50 & 0.40 & 1.00 & 0.119 & 0.019 & 0.084 & 0.160 & 0.629 & 0.179 & Trace & 0.145 \\
\hline 6 & Balijuri & BW & 9.65 & 311.26 & 250.00 & 0.40 & Trace & 3.00 & 0.50 & 0.80 & 0.108 & 0.006 & 0.062 & 0.320 & 0.695 & 0.157 & 0.320 & 0.090 \\
\hline 7 & Rajai & BW & 8.18 & 533.76 & 500.00 & 1.00 & Trace & 5.00 & 1.70 & 2.70 & 0.200 & 0.038 & 0.085 & 0.090 & 0.605 & 0.114 & 0.250 & 0.320 \\
\hline 8 & Bhaluka & $\mathrm{BW}$ & 8.65 & 355.84 & 170.00 & 0.40 & 1.00 & 1.00 & 1.00 & 2.40 & 0.141 & 0.040 & 0.104 & 0.118 & 0.493 & 0.231 & Trace & 0.455 \\
\hline 9 & Bhaluka & PW & 9.75 & 333.60 & 190.00 & 1.00 & 2.00 & 0.50 & 0.80 & 2.00 & 0.260 & 0.045 & 0.097 & 0.109 & 0.182 & 0.109 & Trace & 0.380 \\
\hline 10 & Bhaluka & RW & 8.90 & 378.08 & 295.60 & 1.00 & Trace & 3.50 & 0.60 & 2.40 & 0.260 & 0.026 & 0.097 & 0.172 & 0.308 & 0.222 & Trace & 0.320 \\
\hline 11 & Chandalgaon & BW & 9.00 & 311.36 & 300.00 & 1.00 & Trace & 3.00 & 0.60 & 2.00 & 0.217 & 0.012 & 0.052 & 0.290 & 0.752 & 0.183 & Trace & 0.315 \\
\hline 12 & Meduary & BW & 7.95 & 533.76 & 310.00 & 0.60 & Trace & 3.00 & 1.70 & 4.00 & 0.108 & 0.031 & 0.013 & 0.149 & 0.750 & 0.926 & Trace & 0.260 \\
\hline 13 & Meduary & RW & 10.05 & 222.40 & 160.00 & 0.60 & Trace & 1.50 & 1.00 & 0.80 & 0.248 & 0.012 & 0.017 & 0.053 & 0.529 & 0.120 & 0.01 & 0.060 \\
\hline 14 & Lohabari & PW & 9.60 & 378.08 & 300.00 & 0.80 & Trace & 3.50 & 0.40 & 1.20 & 0.173 & 0.009 & 0.039 & 0.230 & 0.594 & 0.117 & 0.104 & 0.310 \\
\hline 15 & Habirbari & $\mathrm{CW}$ & 10.13 & 378.08 & 279.00 & 0.60 & Trace & 3.50 & 0.40 & 0.70 & 0.217 & 0.015 & 0.060 & 0.230 & 1.795 & 0.067 & 0.170 & 0.520 \\
\hline 16 & Gadumeah & $\mathrm{CW}$ & 8.00 & 333.00 & 250.30 & 0.80 & Trace & 3.00 & 0.70 & 1.10 & 0.282 & 0.015 & 0.156 & 0.086 & 0.088 & 0.082 & 0.110 & 0.660 \\
\hline 17 & Bhandabo & BW & 4.00 & 289.00 & 110.50 & 2.00 & Trace & 2.00 & 0.20 & 0.40 & 0.086 & 0.012 & 0.062 & Trace & 0.452 & 0.231 & 0.010 & 0.320 \\
\hline \multicolumn{3}{|c|}{ Range } & $\begin{array}{l}4.00 \\
- \\
10.13\end{array}$ & $\begin{array}{c}177.92 \\
- \\
533.76 \\
\end{array}$ & $\begin{array}{l}110.50- \\
500.00\end{array}$ & $\begin{array}{l}0.40 \\
- \\
2.00 \\
\end{array}$ & $\begin{array}{l}\text { Trace } \\
- \\
2.00\end{array}$ & $\begin{array}{l}0.50 \\
- \\
5.00 \\
\end{array}$ & $\begin{array}{l}0.10 \\
- \\
1.70\end{array}$ & $\begin{array}{l}0.40 \\
- \\
4.00\end{array}$ & $\begin{array}{l}0.086 \\
- \\
0.282\end{array}$ & $\begin{array}{l}0.006 \\
- \\
0.045\end{array}$ & $\begin{array}{l}0.017 \\
- \\
0.156\end{array}$ & $\begin{array}{l}\text { Trace } \\
- \\
0.320\end{array}$ & $\begin{array}{l}0.088 \\
- \\
1.795\end{array}$ & $\begin{array}{l}0.030 \\
- \\
0.926\end{array}$ & $\begin{array}{l}\text { Trace } \\
- \\
0.320\end{array}$ & $\begin{array}{l}0.090 \\
- \\
0.660\end{array}$ \\
\hline \multicolumn{3}{|c|}{ Mean } & 8.38 & 358.40 & 264.79 & 0.75 & - & 2.88 & 0.72 & 1.67 & 0.17 & 0.02 & 0.070 & 0.170 & 0.620 & 0.190 & 0.092 & 0.300 \\
\hline \multicolumn{3}{|c|}{ SD } & 1.75 & 89.63 & 91.14 & 0.39 & - & 1.19 & 0.45 & 0.93 & 0.07 & 0,01 & 0.030 & 0.090 & 0.370 & 0.200 & 0.110 & 0.150 \\
\hline \multicolumn{3}{|c|}{$\% \mathrm{CV}$} & 19.51 & 25.01 & 34.42 & 52.09 & - & 41.42 & 62.22 & 55.92 & 38.66 & 57.91 & 49.49 & 51.85 & 59.33 & 105.26 & 122.22 & 50.24 \\
\hline
\end{tabular}


Properties of surface water in Madhupur tract

Table 2. Quality rating and suitability of water samples for irrigation

\begin{tabular}{|c|c|c|c|c|c|c|c|c|c|c|c|c|c|c|c|c|c|c|c|c|c|}
\hline \multirow{2}{*}{$\begin{array}{l}\text { Samle } \\
\text { no. }\end{array}$} & \multicolumn{2}{|c|}{$\mathrm{pH}$} & \multicolumn{2}{|c|}{ EC } & \multicolumn{2}{|c|}{ TDS } & \multicolumn{2}{|c|}{ SAR } & \multicolumn{2}{|c|}{ SSP } & \multicolumn{2}{|c|}{ RSC } & \multicolumn{2}{|c|}{$\mathrm{H}_{\mathrm{T}}$} & \multirow{2}{*}{$\begin{array}{l}\text { Alkalinity and } \\
\text { salinity hazard }\end{array}$} & \multicolumn{2}{|c|}{$\mathrm{Mn}$} & \multicolumn{2}{|c|}{$\mathrm{Cu}$} & \multicolumn{2}{|c|}{ B } \\
\hline & Value & Clas & $\mu \mathrm{Scm}^{-1}$ & Class & $\mathrm{mgL}^{-1}$ & Class & Ratio & Class & $\%$ & Class & $\mathrm{meL}^{-1}$ & Class & $\mathrm{mgL}^{-1}$ & Class & & $\mathrm{mgL}^{-1}$ & Class & $\mathrm{mgL}^{-1}$ & Class & $\mathrm{mgL}^{-1}$ & Class \\
\hline 1 & 4.25 & Unsuit. & 177.92 & Ex. & 150.00 & FW & 0.106 & Ex & 7.86 & Ex & 0.20 & Suit. & 64.78 & Soft & $\mathrm{C} 2 \mathrm{~S} 1$ & 0.169 & Suit. & 0.120 & Suit & 0.310 & Ex. \\
\hline 2 & 9.32 & Unsuit. & 378.08 & Good & 310.50 & FW & 0.117 & Ex & 6.56 & Ex & 2.30 & Mar. & 84.82 & $\mathrm{MH}$ & $\mathrm{C} 2 \mathrm{~S} 1$ & 0.206 & Unsuit. & 0.280 & Unsuit & 0.240 & Ex \\
\hline 3 & 8.20 & Suit. & 400.32 & Good & 335.50 & FW & 0.141 & Ex & 6.10 & Ex & 1.00 & Suit. & 149.67 & $\mathrm{MH}$ & C2S1 & 0.081 & $\begin{array}{l}\text { Suit. } \\
\end{array}$ & 0.220 & Unsuit & 0.210 & Ex \\
\hline 4 & 8.50 & Suit & 378.08 & Good & 300.00 & FW & 0.128 & Ex & 5.46 & Ex & 0.30 & Suit. & 159.68 & $\mathrm{H}$ & $\mathrm{C} 2 \mathrm{~S} 1$ & 0.030 & Suit. & 0.190 & Suit & 0.180 & Ex \\
\hline 5 & 8.330 & Suit & 400.32 & Good & 290.50 & FW & 0.142 & Ex & 8.97 & Ex & 2.10 & Mar & 69.86 & Soft & $\mathrm{C} 2 \mathrm{~S} 1$ & 0.179 & Suit. & 0.160 & Suit & 0.145 & Ex \\
\hline 6 & 9.65 & Unsuit. & 311.26 & Good & 250.00 & FW & 0.133 & Ex & 8.06 & Ex & 1.70 & Mar. & 64.91 & Soft & C2S1 & 0.157 & Suit. & 0.320 & Unsuit & 0.090 & Ex \\
\hline 7 & 8.18 & Suit & 533.76 & Good & 500.00 & FW & 0.134 & Ex & 5.13 & Ex & 0.60 & Suit. & 219.69 & $\mathrm{H}$ & $\mathrm{C} 2 \mathrm{~S} 1$ & 0.114 & Suit. & 0.090 & Suit & 0.320 & Ex \\
\hline 8 & 8.65 & Unsuit. & 355.84 & Good & 170.00 & FW & 0.106 & Ex & 5.05 & Ex & -1.40 & Mar. & 169.68 & $\mathrm{MH}$ & $\mathrm{C} 2 \mathrm{~S} 1$ & 0.231 & Unsuit & 0.118 & Suit & 0.455 & Good \\
\hline 9 & 9.75 & Unsuit. & 333.60 & Good & 190.00 & FW & 0.219 & Ex & 9.82 & Ex & -1.30 & Suit. & 139.71 & $\mathrm{MH}$ & $\mathrm{C} 2 \mathrm{~S} 1$ & 0.109 & Suit. & 0.109 & Suit. & 0.380 & Good \\
\hline 10 & 8.90 & Unsuit. & 378.08 & Good & 295.60 & FW & 0.212 & Ex & 8.70 & Ex & 0.50 & Suit. & 149.64 & MH & $\mathrm{C} 2 \mathrm{~S} 1$ & 0.222 & Unsuit & 0.172 & Suit & 0.320 & Ex \\
\hline 11 & 9.00 & Unsuit. & 311.36 & Good & 300.00 & FW & 0.190 & Ex & 8.09 & Ex & 0.40 & Mar. & 129.69 & MH & $\mathrm{C} 2 \mathrm{~S} 1$ & 0.183 & Suit. & 0.290 & Unsuit & 0.315 & Ex \\
\hline 12 & 7.95 & $\begin{array}{l}\text { Suit } \\
\end{array}$ & 533.76 & Good & 310.00 & FW & 0.063 & Ex & 2.38 & Ex & -2.70 & Suit. & 284.45 & $\mathrm{H}$ & C2S1 & 0.926 & Unsuit & 0.149 & $\begin{array}{l}\text { Suit } \\
\end{array}$ & 0.260 & Ex \\
\hline 13 & 10.05 & Unsuit. & 222.40 & Ex. & 160.00 & FW & 0.261 & Ex & 8.49 & Ex & -0.30 & Suit. & 89.96 & MH & C1S1 & 0.120 & Suit. & 0.053 & Suit & 0.060 & Ex \\
\hline 14 & 9.60 & Unsuit. & 378.08 & Good & 300.00 & FW & 0.193 & Ex & 10.21 & Ex & 1.90 & Mar. & 79.81 & $\mathrm{MH}$ & $\mathrm{C} 2 \mathrm{~S} 1$ & 0.117 & Suit. & 0.230 & Unsuit & 0.310 & Ex \\
\hline 15 & 10.13 & Unsuit. & 378.08 & Good & 279.00 & FW & 0.292 & Ex & 17.41 & Ex & 2.40 & Mar. & 74.82 & Soft & $\mathrm{C} 2 \mathrm{~S} 1$ & 0.067 & Suit. & 0.230 & Unsuit & 0.520 & Good \\
\hline 16 & 8.00 & Suit & 333.00 & Good & 250.30 & FW & 0.297 & Ex & 14.14 & Ex & 1.20 & Suit. & \begin{tabular}{|l|}
79.88 \\
\end{tabular} & MH & C2S1 & 0.082 & Suit. & 0.086 & Suit. & 0.660 & Good \\
\hline 17 & 4.00 & Unsuit. & 289.00 & Good & 110.50 & FW & 0.157 & Ex & 14.04 & Ex & 2.40 & Mar. & 29.94 & Soft & $\mathrm{C} 2 \mathrm{~S} 1$ & 0.231 & Unsuit & Trace & Suit & 0.320 & Ex \\
\hline
\end{tabular}

Legend: Trace $<0.001 \mathrm{mg} \mathrm{L}^{-1}, \mathrm{FW}=$ Fresh water, Ex. = Excellent, $\quad$ Suit. = Suitable, Unsuit.= Unsuitable Mar.= Marginal, H= Hard water, MH = Moderately Hard water , C2= Medium Salinity and $\quad$ S1=Low

alkalinity. $\mathrm{H}_{\mathrm{T}}=$ Hardness.

Table 3. Quality rating and suitability of water samples for aquaculture

\begin{tabular}{|c|c|c|c|c|c|c|c|c|c|c|c|c|c|c|c|c|c|c|c|c|}
\hline \multirow{2}{*}{$\begin{array}{l}\text { Samle } \\
\text { no. }\end{array}$} & \multicolumn{2}{|c|}{$\mathrm{pH}$} & \multicolumn{2}{|c|}{ TDS } & \multicolumn{2}{|c|}{$\mathrm{H}_{\mathrm{T}}$} & \multicolumn{2}{|c|}{ Са } & \multicolumn{2}{|c|}{ Mg } & \multicolumn{2}{|c|}{$\mathrm{Zn}$} & \multicolumn{2}{|c|}{$\mathrm{Cu}$} & \multicolumn{2}{|c|}{$\mathrm{Fe}$} & \multicolumn{2}{|c|}{$\mathrm{Mn}$} & \multicolumn{2}{|c|}{$\mathrm{Na}$} \\
\hline & Value & Clas & $\mathrm{mgL}^{-1}$ & Class & $\mathrm{mgL}^{-1}$ & Class & $\mathrm{mgL}^{-1}$ & Class & $\mathrm{mgL}^{-1}$ & Class & $\mathrm{mgL}^{-1}$ & Class & $\mathrm{mgL}^{-1}$ & Class & $\mathrm{mgL}^{-1}$ & Class & $\mathrm{mgL}^{-1}$ & Class & $\mathrm{mgL}^{-1}$ & Class \\
\hline 1 & 4.25 & Unsuit. & 150.00 & Suit. & 64.78 & Suit & 2.00 & Suit & 14.58 & Suit. & 0.086 & Unsuit & 0.120 & Unsuit & 0.721 & Unsuit & 0.169 & Unsuit & 1.98 & Suit \\
\hline 2 & 9.32 & Unsuit. & 310.50 & Suit. & 84.82 & Suit & 10.02 & Suit & 14.58 & Suit & 0.040 & Unsuit & 0.280 & Unsuit & 0.928 & Unsuit & 0.206 & Unsuit & 2.48 & Suit \\
\hline 3 & 8.20 & Unsuit & 335.50 & Suit. & 149.67 & Suit & 16.04 & Suit & 26.74 & Unsuit. & 0.076 & Unsuit & 0.220 & Unsuit & 0.530 & Unsuit & 0.081 & Unsuit & 3.98 & Suit \\
\hline 4 & 8.50 & Unsuit & 300.00 & Suit. & 159.68 & Suit & 18.04 & Suit & 27.95 & Unsuit. & 0.075 & Unsuit & 0.190 & Unsuit & 0.546 & Unsuit & 0.030 & Unsuit & 3.75 & Suit \\
\hline 5 & 8.330 & Unsuit & 290.50 & Suit. & 69.86 & Suit & 8.02 & Suit & 12.15 & Suit & 0.084 & Unsuit & 0.160 & Unsuit & 0.629 & Unsuit & 0.179 & Unsuit & 2.74 & Suit \\
\hline 6 & 9.65 & Unsuit. & 250.00 & Suit. & 64.91 & Suit & 10.02 & Suit & 9.72 & Suit & 0.062 & Unsuit & 0.320 & Unsuit & 0.695 & Unsuit & 0.157 & Unsuit & 2.48 & Suit \\
\hline 7 & 8.18 & Unsuit & 500.00 & Unsuit. & 219.69 & Suit & 30.07 & Suit & 32.81 & Unsuit. & 0.085 & Unsuit & 0.090 & Unsuit & 0.605 & Unsuit & 0.114 & Unsuit & 4.6 & Suit \\
\hline 8 & 8.65 & Unsuit. & 170.00 & Suit. & 169.68 & Suit & 20.04 & Suit & 29.16 & Unsuit. & 0.104 & Unsuit & 0.118 & Unsuit & 0.493 & Unsuit & 0.231 & Unsuit & 3.24 & Suit \\
\hline 9 & 9.75 & Unsuit. & 190.00 & Suit. & 139.71 & Suit & 16.03 & Suit & 24.31 & Unsuit. & 0.097 & Unsuit & 0.109 & Unsuit & 0.182 & Unsuit & 0.109 & Unsuit & 5.98 & Suit \\
\hline 10 & 8.90 & Unsuit. & 295.60 & Suit. & 149.64 & Suit & 12.02 & Suit & 29.17 & Unsuit. & 0.097 & Unsuit & 0.172 & Unsuit & 0.308 & Unsuit & 0.222 & Unsuit & 5.98 & Suit \\
\hline 11 & 9.00 & Unsuit. & 300.00 & Suit. & 129.69 & Suit & 12.02 & Suit & 24.31 & Unsuit. & 0.052 & Unsuit & 0.290 & Unsuit & 0.752 & Unsuit & 0.183 & Unsuit & 4.99 & Suit \\
\hline 12 & 7.95 & Suit. & 310.00 & Suit. & 284.45 & Suit & 34.07 & Suit & 48.61 & Unsuit. & 0.013 & Unsuit & 0.149 & Unsuit & 0.750 & Unsuit & 0.926 & Unsuit & 2.48 & Suit \\
\hline 13 & 10.05 & Unsuit. & 160.00 & Suit. & 89.96 & Suit & 20.04 & Suit & 9.72 & Suit. & 0.017 & Unsuit & 0.053 & Unsuit & 0.529 & Unsuit & 0.120 & Unsuit & 5.70 & Suit \\
\hline 14 & 9.60 & Unsuit. & 300.00 & Suit. & 79.81 & Suit & 8.02 & Suit & 14.58 & Suit. & 0.039 & Unsuit & 0.230 & Unsuit & 0.594 & Unsuit & 0.117 & Unsuit & 3.98 & Suit \\
\hline 15 & 10.13 & Unsuit. & 279.00 & Suit. & 74.82 & Suit & 8.02 & Suit & 8.51 & Suit & 0.060 & Unsuit & 0.230 & Unsuit & 1.795 & Unsuit & 0.067 & Unsuit & 4.99 & Suit \\
\hline 16 & 8.00 & Suit. & 250.30 & Suit. & 79.88 & Suit & 14.3 & Suit & 13.37 & Suit. & 0.156 & Unsuit & 0.086 & Unsuit & 0.088 & Unsuit & 0.082 & Unsuit & 6.49 & Suit \\
\hline
\end{tabular}


Nizam et al (2014), Progressive Agriculture 25: 9-16

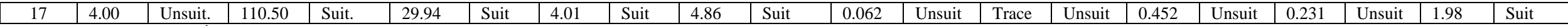
Legend: Trace $<0.001 \mathrm{mgL}^{-1}$, Suit.= Suitable, Unsuit.= Unsuitable, $\mathrm{H}_{\mathrm{T}}=$ Hardness

Table 4. Suitability test of water samples for livestock consumption

\begin{tabular}{|c|c|c|c|c|c|c|c|c|c|c|c|c|c|c|}
\hline \multirow[t]{2}{*}{ Samle no. } & \multicolumn{2}{|c|}{ TDS } & \multicolumn{2}{|c|}{$\mathrm{H}_{\mathrm{T}}$} & \multicolumn{2}{|c|}{$\mathrm{Cl}$} & \multicolumn{2}{|c|}{$\mathrm{Fe}$} & \multicolumn{2}{|c|}{ Mn } & \multicolumn{2}{|c|}{$\mathrm{Zn}$} & \multicolumn{2}{|c|}{$\mathrm{Cu}$} \\
\hline & $\mathrm{mgL}^{-1}$ & Class & $\mathrm{mgL}^{-1}$ & Class & $\mathrm{mgL}^{-1}$ & Class & $\mathrm{mgL}^{-1}$ & Class & $\mathrm{mgL}^{-1}$ & Class & $\mathrm{mgL}^{-}$ & Class & $\mathrm{mgL}^{-}$ & Class \\
\hline 1 & 150.00 & Suit. & 64.78 & Suit. & 14.20 & Suit. & 0.721 & Unsuit. & 0.169 & Unsuit. & 0.086 & Suit & 0.120 & Suit \\
\hline 2 & 310.50 & Suit. & 84.82 & Suit. & 21.30 & Suit. & 0.928 & Unsuit. & 0.206 & Unsuit. & 0.040 & Suit & 0.280 & Suit \\
\hline 3 & 335.50 & Suit. & 149.67 & Suit & 21.30 & Suit. & 0.530 & Unsuit. & 0.081 & Unsuit. & 0.076 & Suit & 0.220 & Suit \\
\hline 4 & 300.00 & Suit. & 159.68 & Suit. & 14.20 & Suit. & 0.546 & Unsuit. & 0.030 & Suit & 0.075 & Suit & 0.190 & Suit \\
\hline 5 & 290.50 & Suit. & 69.86 & Suit. & 21.30 & Suit. & 0.629 & Unsuit. & 0.179 & Unsuit. & 0.084 & Suit & 0.160 & Suit \\
\hline 6 & 250.00 & Suit. & 64.91 & $\begin{array}{l}\text { Suit. } \\
\end{array}$ & 14.20 & $\begin{array}{l}\text { Suit. } \\
\end{array}$ & 0.695 & Unsuit. & 0.157 & Unsuit. & 0.062 & Suit & 0.320 & Suit \\
\hline 7 & 500.00 & Suit. & 219.69 & Unsuit. & 35.50 & Unsuit. & 0.605 & Unsuit. & 0.114 & Unsuit. & 0.085 & Suit & 0.090 & Suit \\
\hline 8 & 170.00 & Suit. & 169.68 & Suit. & 14.20 & Suit. & 0.493 & Unsuit. & 0.231 & Unsuit. & 0.104 & Suit & 0.118 & Suit \\
\hline 9 & 190.00 & Suit. & 139.71 & Suit. & 35.50 & Unsuit. & 0.182 & Suit & 0.109 & Unsuit. & 0.097 & Suit & 0.109 & Suit \\
\hline 10 & 295.60 & Suit. & 149.64 & Suit & 35.50 & Unsuit. & 0.308 & Unsuit. & 0.222 & Unsuit. & 0.097 & Suit & 0.172 & Suit \\
\hline 11 & 300.00 & Suit. & 129.69 & Suit. & 35.50 & Unsuit. & 0.752 & Unsuit. & 0.183 & Unsuit. & 0.052 & Suit & 0.290 & Suit \\
\hline 12 & 310.00 & Suit. & 284.45 & Unsuit & 21.30 & Suit. & 0.750 & Unsuit. & 0.926 & Unsuit. & 0.013 & Suit & 0.149 & Suit \\
\hline 13 & 160.00 & Suit. & 89.96 & Suit & 21.30 & Suit. & 0.529 & Unsuit. & 0.120 & Unsuit. & 0.017 & Suit & 0.053 & Suit \\
\hline 14 & 300.00 & Suit. & 79.81 & Suit & 28.40 & Suit. & 0.594 & Unsuit. & 0.117 & Unsuit. & 0.039 & Suit & 0.230 & Suit \\
\hline 15 & 279.00 & Suit. & 74.82 & Suit & 21.30 & Suit. & 1.795 & Unsuit. & 0.067 & Unsuit. & 0.060 & Suit & 0.230 & Suit \\
\hline 16 & 250.30 & Suit. & 79.88 & Suit. & 28.40 & Suit. & 0.088 & Suit & 0.082 & Unsuit. & 0.156 & Suit & 0.086 & Suit \\
\hline 17 & 110.50 & Suit. & 29.94 & Suit. & 71.00 & Unsuit. & 0.452 & Unsuit. & 0.231 & Unsuit. & 0.062 & Suit & Trace & Suit \\
\hline
\end{tabular}

Legend: Trace $<0.001 \mathrm{mgL}^{-1}$, Suit.= Suitable, Unsuit.= Unsuitable , $\mathrm{H}_{\mathrm{T}}=$ Hardness 
Ayers RS, Westcot DW (1985). Water quality for Agriculture. FAO Irrigation and Drainage Paper 29 (Rev.I): 1-144

Bohn HL, McNea BLO, Conner GA (1985). Soil Chemistry. $2^{\text {nd }}$ Edn. John Wiley and Sons. New York.

Chopra SL, Kanwar JS (1991). Analytical Agricultural Chemistry. 4th. Edn. Kalyani Publishers, Ludiana, New Deihi.

Davis SN, Weist De RJM (1966). Hydrology. John Wiley and Sons. New York.

Eaton FM (1950). Significance of Carbonation Irrigation Waters. Soil Science 67: 12133.

Freeze AR, Cherry JA (1979). Groundwater. Prentice Hall Inc. England Cliffs, New Jersey 07632: 84-387.

Goel PK (2006). Water Pollution Causes Effects and Control. $2^{\text {nd }}$ Edn. New Age International Publishers, New Delhi.

Gomez KA, Gomez AA (1984). Statistical Procedures for Agricultural Research. $2^{\text {nd }}$. Edn. John Wiley and Sons. New York.

Karanth KR (1994). Groundwater Assessment Development and Management. TATA Mc Graw-Hill Publishing Co. Ltd. New Delhi.

Karim MF, Zaman MW, Sultana R, Nizam MU, TOdd DK (1980). Groundwater Hydrology. $2^{\text {nd }}$ Edn. Kamuzzaman MR (2013). Chemical Quality of Surface Water of Bhola Sadar Upazila in Bangladesh for Irrigation , Aquaculture, Drinking and Livestock Consumption . J. Environ. Sci. \& Natural Resources. 6 (1): 131-140.

Meade JW (1989). Aquaculture Management. New York.Van Nostrand Reinhold.

Michael AM (1997). Irrigation Theory and Practice. Vikas Publishing House Pvt. Ltd. New Delhi.

Mishra RD, Ahmed M (1993). Manual on Irrigation Agronomy. Oxford and IBH Publishing Co. Pvt. Ltd. New Delhi.

Nizam MU, Shariful MI, Islam MS (2010). Quality assessment of surface water resources of
Dumki Upazila in Bangladesh for irrigation, aquaculture and livestock consumption. J. Agrofor. Environ. 4(2): 81-84.

Page AL, Miller RH, Kenny DR (1982). Methods of Soil Analysis. Part-2. Chemical and Microbial Properties. $2^{\text {nd }}$ Edn. American Society of Agronomy, Inc. Soil Science Society of American Inc. Madison, Wisconsin, USA.

Richards LA (1968). Diagnosis and Improvement of Saline and Alkali Soils. Agricultural Handbook USDA and IBH. Publishing Co. Ltd. New Delhi, India.

Sawyer CN, McCarty PL (1967). Chemistry for Sanitary Engineers. $2^{\text {nd }}$. Edn. McGraw Hill, New York.

Tandon HLS (1995). Methods of Analysis of Soil, Plants, Water and Fertilizers. Fertilizer Development and Consultation Organization. New Delhi.

Taslima A (2012). Quantitive assessment of ionic status of pond water for irrigation and aquaculture usage inthe selected sites of Mymensingh area. MS Thesis. Department of Agricultural Chemistry, Bangladesh Agricultural University, Mymensingh. Jhon Wiley and Sons. Inc. New York 10016.

Upadhyay RM, Sharma NL (2002). Manual of Soil, Plant, Water and Fertilizer Analysis. Kalyani Publishers, Ludiana, New Deihi.

Varshney CK (2002). Water Pollution and Management. New Age International Publishers, New Delhi.

Wilcox LV (1955). Classification and Use of Irrigation Water. United States Department of Agriculture. Circular No. 969. Washington D.C.

Zaman MW, Rahman MM (1996). Ionic Toxicity of Industrial Process Waters in some Selected Sites of Sirajgonj in Bangladesh. Bangladesh J. Environ. Science.2: 27-34. 